（126）連続鋳造のモールド内不均一凝固におよほす鋳込流の影響

住友金属 中央技術研究所 佐々木寛太郎 杉谷泰夫 三浦 実。渡部忠男

1. 緒 言

スラブの連続鋳造において, モールド内に形成する凝固シェルには, 局部的な凝固遅れ部位が存在 する。このモールド内の不均一凝固には種々の要因が関与するか, 本報では, 鋳込流の影響について 報告する。

2. 調查方法

(1) 連続鋳造実験装置（モールドサイズ：156×1070）に, 約 2 トンの溶鋼 $(0.1 \%$ C) を鋳 込み, 所定長さに引き抜き後, 未凝固溶鋼を強制的に排出する方法により,モールド内凝固シェル の形成状況を調查した。

(2) 一定流速の溶鋼噴流（ $\mathrm{V}_{\mathrm{o}}=40 \sim 120 \mathrm{~cm} / \mathrm{sec}, 0.1 \% \mathrm{C}$ ) を水冷銅壁 $(240 \times 500)$ 亿直角飞 衝突させ, 所定時間経過後, モールド内溶鋼を強制 的に排出する。得られた凝固シェル形状から,一次 鋳込流の衝突領域における凝固遅れを測定した。

3. 調查結果

$3-1$. 浸漬ノズル形状の影響

形状の異なる三種の浸漬ノズル（2 孔逆Y $25 ; 4$ 孔水平, 6 孔水平) を用いて, 凝固シェル形成におよ

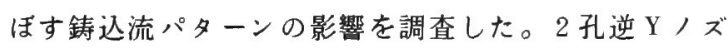
ルで鋳込むと, 図1, 写真 1 亿示すように, 隅角部の 凝固遅れが顕著である。一方, 多孔水平ノズルの場合 には, 凝固遅れ部位か，広幅面中央部の特定位置に生 ずる。このように, 連続鋳造モールド内でのマク口的 な凝固遅れ部位は, 浸漬ノズル形状に依存する。

\title{
$3-2$. 鋳込溶䤱流速の影響
}

鋳込溶鋼流衝突部の平均凝固係数之, 鋳込噴流流速 の関係を図 2 に示す。鋳込溶鏰流速の增大とともに, 凝固係数は低下する。また, 凝固シェルの調查から, 鋳込衝突流に上る凝固遅れは, 特に凝固初期に顕著で あることもわかった。

図 2 の結果から求めた凝固シェルの凝固遅机率は, 実機の連続鋳造モールド内凝固シェルの凝固遅れ部実 測値とよく一致する。

\section{4. 結 言}

連続鋳造モールド内の凝固シェルのマクロ的な凝固 の不均一は, 浸漬, ズル形状に依存する。

凝固遅れの度合いは、鋳込溶鋼流速の大きさに依存 する。

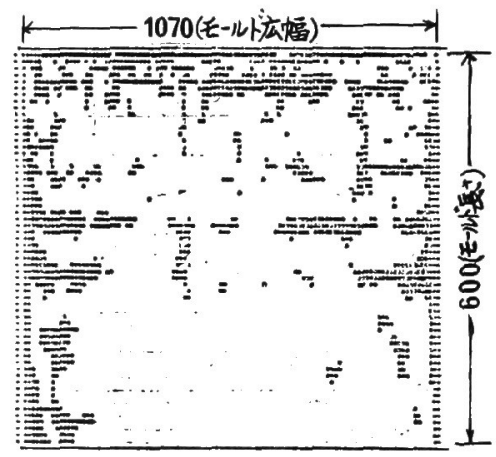

図1. 凝固シェル広幅面各部の凝固遅れ部 の分布（上端；メ二スカス部, 下端：モ ールド出口部, ○印：凝固遅れ部)

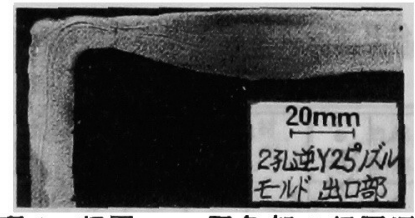

与真 1. 凝固シェル隅角部の疑固遅れ状況

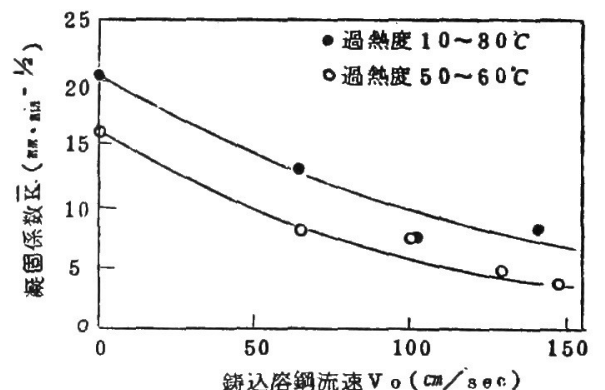

図 2. 凝固係数におよほす鋳込流速の影響 
（127）連続鋳造のモールド内擬固について

I 粕 言

連続鍀造技術はこて数年めさむしい発展をとげ、大をな問題は大体において解决されてをた。残る問 題の一つとしては、連続鋳造の生産性を大をくして行くといらととがあり、このためにはモールドの断

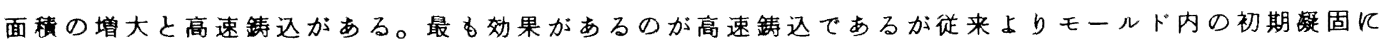

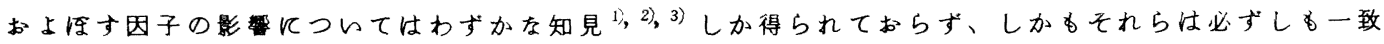
した結論を出していない。そててサルファ一添加法に上りモールド内初期凝固について調査したので、 その結果を報告する。

II調查方法

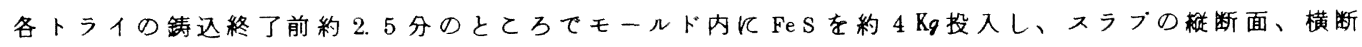
面のサルフォープリントにより㽰固ンェルの発達状涚を調査した。

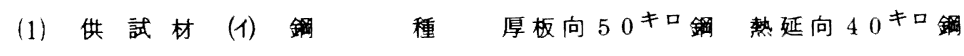

(ロ) スラブサイズ $220 \times 1575270 \times 1275$

(2) 実験内容高速鋳込、各種モールド使用実験

(3) 調査内容 サルファーブリント、テンドライトエッチ、表面蜘調査

III 調査結果と考察

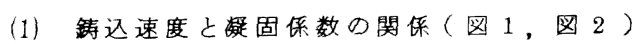

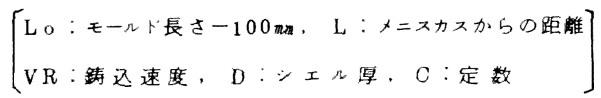

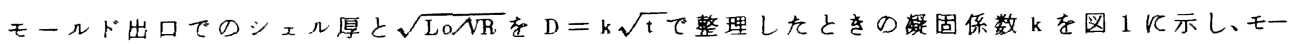

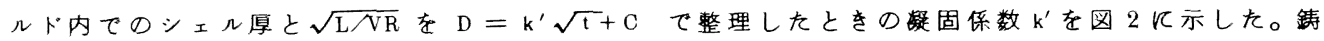
造速度に対して傾向は全く逆であるが、てれは速度の大小によりメニスカス直下のシェルの発達状 況が異なるためである。すなわち、これは䤻込速度の因子が疑固開始点と疑固シェルのモールドか らの剥離の時期飞影をおよ結果と考えられる。

(2) モールドテーバーの影譬（四 3 ）

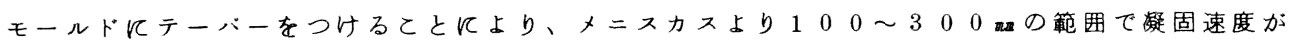

特に大をくなり、とのととろでンェルの剩離が㧕制されている。

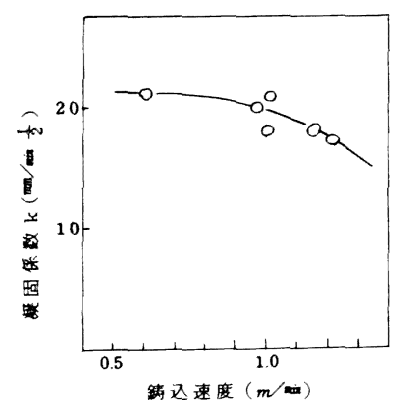

図 1 䥀入速度と疑固保数の関係

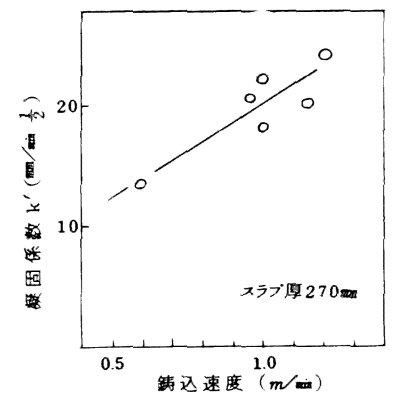

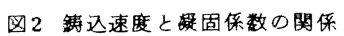

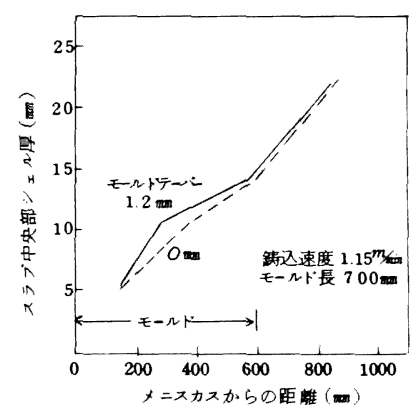

因了シェ几発達にお上ほすモールト テーパーの影等
文献 1) 小沢等：鉄と鋼，62（1976), S86
2)熊井等: 铁と鋼, $60(1974), 894 \sim 914$
3) 三本木等：学振第 19 委, 凝固現象協議会、1976 
（128）連鋳鋳型内鋳片コーナー部疑固遅れ回復に関する 2,3 の検討

神戸製銿所中央研究所

鉄鉱生廉本部
成田貫一。森隆盗

綾田研三宮崎純

副島利行宮下隆夫

1. 緒 言

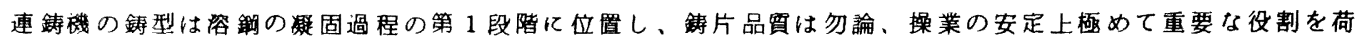
って居る。とのため、鋳型の佮却特性を知っておくととは、鋳片品貿の向上はもとより、ブレークアウト防

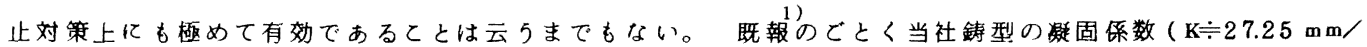
min $1 / 2)$ 加他の報告值( $\left.{ }^{3} \mathrm{~K}=18 \sim 24\right)$ 亿比べ大きい理由は、「鋳型 の長さが長く、鋳型内で鋳片が琏張し、鋳片と鋳型壁間の熱云䢙が 鋳型下部で回復したためであるとと」を明らかにした。また同時て 「鋳型コーナ一部の命却は中央部に比べて劣っていること」を明らか てした。困1はその1副である。そとで今回鋳型出口近傍の鋳片 凝固厚さを均一にする対策について検討した結果を報告する。

2. 方法および結果

鋳型内の鋳片コーナ一部を鋳型下方で、スプレーはどにより直接 冷却出来る鋳型（Open corner mold） を用いた所、著しい改善 効果か認められた。四2 はその改善された錆片コーナー部の1例 である。四中破線は従来の鋳型、実線は改良鋳型を用いた場合で ある。四より明らかなよ5に、鏻型の改良によりコーナ一部の凝 固か大巾に改善されているととが判る。上記結果を鋳片中央部の 㠜固の発達経過と比べたものか四3である。すなわち、 $\sqrt{t}=1.0$ 近傍から鋳片コーナ一部をスプレーで直接命却した場合で、困中一 点鑚線は鋳片中央部、破線は従来型鋳型コーナ一部、実線は改良鋳 型コーナ一部の鋳片疑固発達の経過を示す。四から明らかなよ

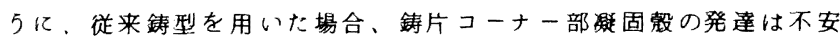
定であり、かつ䐅れる傾向にあるか、実線で示す改良鋳型の場合は 鋳片中央部凝固榜の厚さに匹敵する迄、容易に回復させる事か出来る。

\section{3. 結 論}

鋳型出ココー+一付近で起るブレークアウトは、錆型内鋳片のコ 一ナ一部疑固殼の発達が遅れるととによる場合か多い。とのため 鋳型内の鋳片コーナ一近傍をスプレーにより直接冷却する改良鋳型 を用いた結果、鋳型出ロコーナー近傍で発生するブレークアウトを 大巾に軽减させるととか出来た。

4. 文献

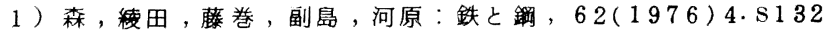

2) 林, 田村：鉄と銅，60(1970)4.S101

3 ）根本：第 12 回西山記急講座 S46.5

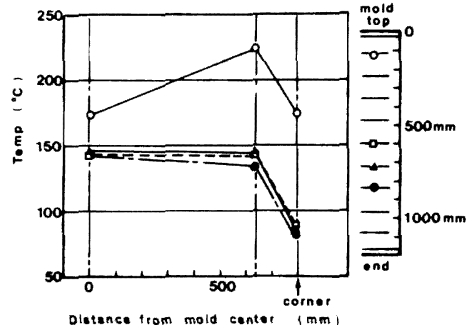

困 1

鋳型広面横方向の温度変化

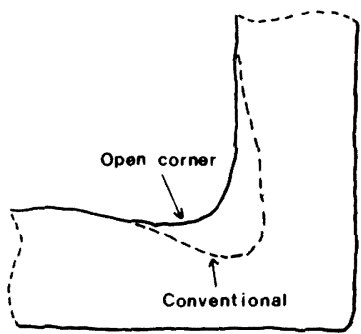

目 2 改良鏻型出口鋳片コーナー 部の㩆固殸の状況

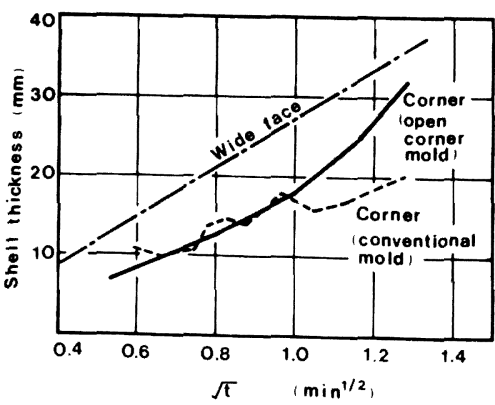

圀3鋳型内鋳片凝固殼の中央部 およびコーナー部の発達状況 
621.746.047: 669.14-722: 620.191.33: 620.172.251.2: 669.141.241.2

'76-S 505

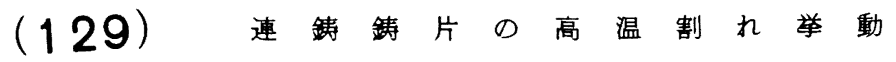

$\begin{aligned} \text { 川崎製鉄技術研究所 } & \text { 木下勝雄河西俉郎 } \\ \text { 理博 } & \text { 江見俊彦 }\end{aligned}$

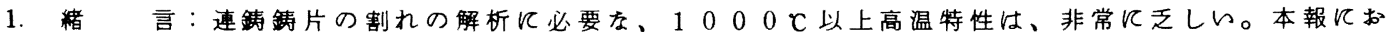
いてこの領域で高温引張試験を行ない、興味ある知見を得た。

2. 万法：試験片を直接誘導加熱する方式では、均一な加熱が難しく、高温引張の特性值の精度と 信頼性が劣る。本実験では、Moサセブターにより試験片を間接加熱することにより、ノッチ周辺や、 平滑試験片の局所的な温度変動を除いた。置を図1.儿示す。师内はAr 䨌囲気にして酸化を防止し た。試験片は連鋳スラブの表面から 30 以内の表居部から採取し、ノッチ底の径あるいは平滑部の 径が、8 $\mathrm{m}$ の丸㔞飞切削した。

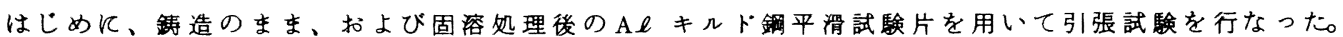
次に、APIX60鍓ノッチ付試験片を熱処理後、種々の冷却速度で所定の温度まで降温し、一定量変形 した。変形後、直ちに除荷して急冷し、ノッチ底に発生した割れ長さを検鏡した。次に、各種の鋼の ノンチ付試験片を用い、固相線直下での脆性選移温度を調べた。

3. 結果: $\mathrm{A} \boldsymbol{l} \neq$ キト鋼の 応力一昰曲楾を図2.儿示す。 引張特性は熱履歴によ! 著し く異なる。高温引張特性を評 価する場合は、熱履歴を再現 して評価する必要がある。 X60 鋼については、熱処理 後の温度が変形温度より降下し なければ、変形温度と割れ長さ の間に図3.に示した関倸が得ら れた。この割れは、すべてオー ステナイト粒界に発生していた。 $900 \sim 950$ Cの間飞顕著に脆 化域があらわれるが、これは従 来報告されている厚板材の脆化 領域（780８80 C ）より高い。

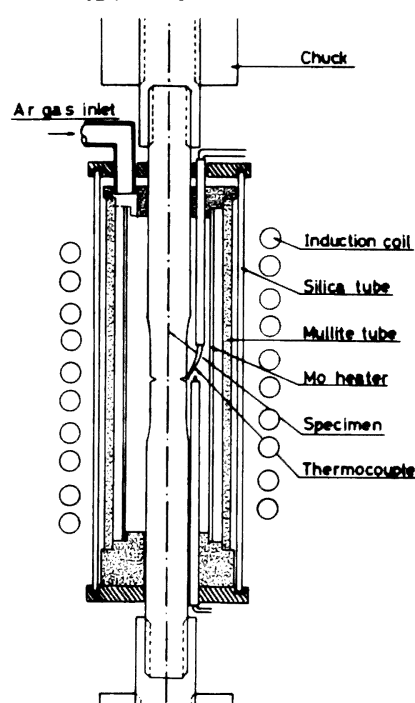

図 1. 高温引張試験機

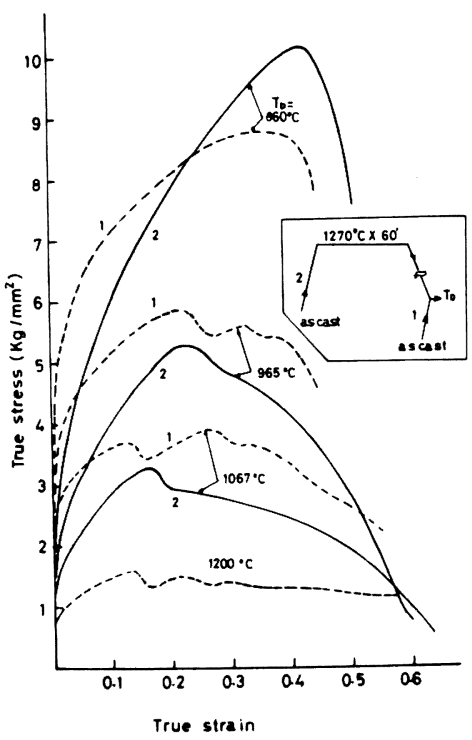

図 2. 50 キロ $\mathrm{A} l$ キルド鋼の応力ー歪曲線 （一様伸びを仮定）

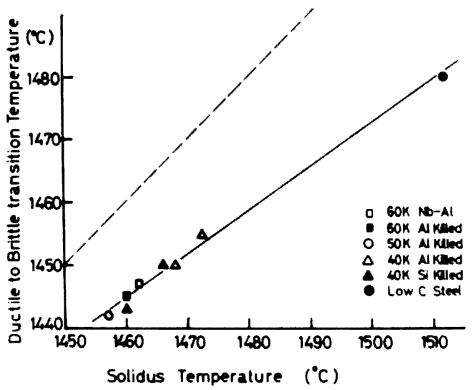

因 4. 脆性要移温度と算出固相楾温度の関俰

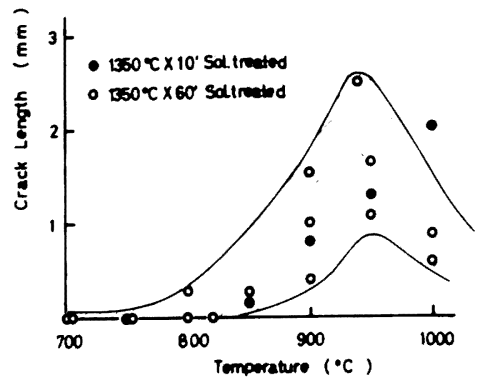

図3、変形温度と割れ長さの関係 


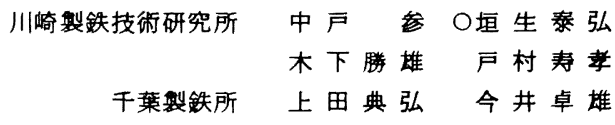

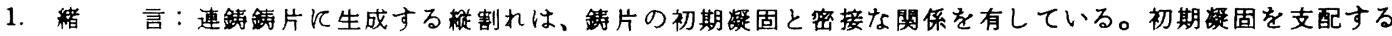

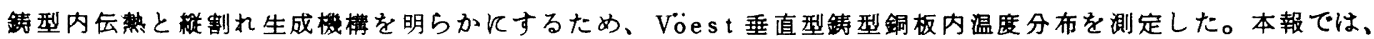

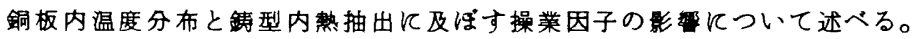

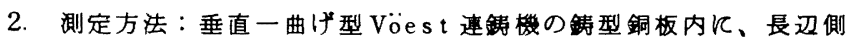
146 本、短辺㑡 30 本、計 176 本の銅一コンスタンタンシース型

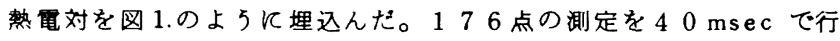
な5高速多点型データ処理置により、同一点を 100 回測定して

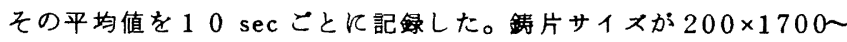
$1900 \mathrm{mn} 、 \mathrm{C} / 0.13 \sim 0.20 、 \mathrm{Mn} / 0.6 \sim 1.5$ (\%)の $\mathrm{Si}-\mathrm{AL}$ および $\mathrm{AL} \neq л$ ド鋼を対象とし、䤶型掵却水量、長短㲽テーバー、鈵型振動条件、 引抜速度、バゥダー性状などの影繁を調査した。本実験は、従来の 報告 ${ }^{1)}$ よりる速い引抜速度 $0.8 \sim 1.4 \mathrm{~m} / \mathrm{min}$ の範囲で行ない、性状 を変えた数多くのバゥダーを用いて鍷型内熱抽出とパウダー性状の 関係を調べた。

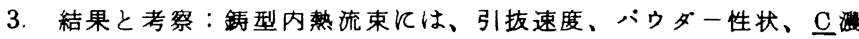
度、タンティッシュ温度の影零が大きく、次いで振動条件で、水量 の影整は小さい。引抜速度の影は、パゥダー銘柄によっても異な るが、0.8 m/min から $1.2 \mathrm{~m} / \mathrm{min}$ 亿增大寸ると約 $10 \%$ の長辺平 均熱流束の增加がある。引抜速度、バゥダ一銘柄が一定の場合、長 辺平均熱流束はタンティッシニ温度が高いはど大きく、溶鋼過熱度 の上䄯にともな5顕熱增加とはほ一致する。銅板内温度の鈜边方向 分布（幅方向平均值）には、図2.の上5に、1)メニスカス付近より 䤡型下端まで順次低下寸る場合(I)、川）鏻型上端より 300 付近 までは順次低下するが、以後型下端まではとんど変化しない場合 （I）、相型下端部で銅板内温度が上年する場合(田)、の3つのタイブ がある。面温度分布の 1 例を図 3. 亿示すが、幅方向の温度分布が均 一でなくかなりの温度差が有る場合も多い。図3.は定常込時のあ る1時刻の測定值であるが、この盜度分布は時刻が変れば、幅方向、 長さ方向に变化するのが特徽である。型内熱流束の 2 次元分布の 時間による複雑な変化を記述するには、スラクの物性の相違によっ て生じる疑固殼／銅板間のスラクフィルム厚とスラクフィルム／銅 板間の凹凸を含めた空隍の 2 次元分布の変化を陽に考庶する必要が あることがわかった。

1）例之ば、甲谷ら：鉄と鋼

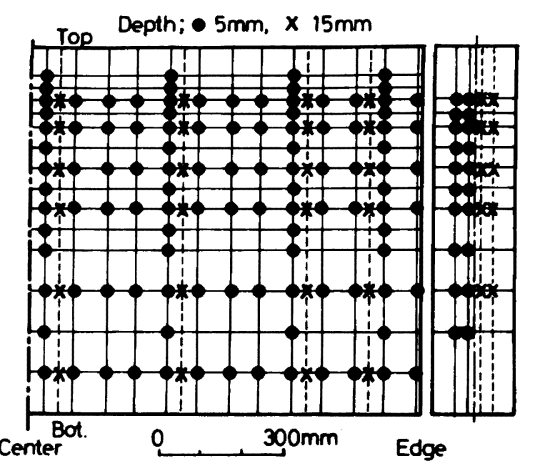

因 1. 銅板内温度測定位置

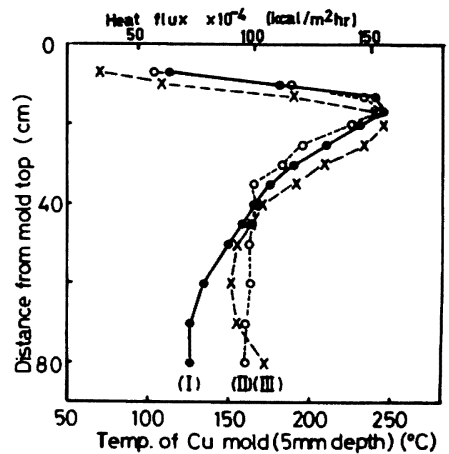

図2. 銅板内 $5 m$ 面温度の制边方向分布

$\geq 230^{\circ} \mathrm{C} \geq 190^{\circ} \mathrm{C}$

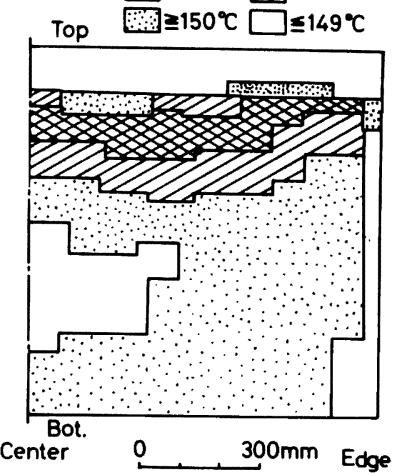

図3. 5 m 面温度の 2 次元分布 


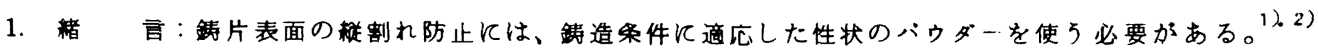
本報では、前報ろ)で示した銅板内温度分布の測定結果などに基つき、パゥダー性状と鈵型内熱抽出状況との関係 について述へる。 表 1. 供試パウダーの性状

2. 実験方法：前報了)の夷験条件でバゥダ一性状のみ を变化させ、鉡型内慗抽出量に及ほす影鳘を調査し た。実験に用いたバゥダーは表 1. 亿示す 8 種であり、 1300 Cでのバゥダー溶破時の站度が $1.6 \sim 17.0$ poiseの節囲にある。

\begin{tabular}{|c|c|c|c|c|c|c|c|c|}
\hline Brand & $\begin{array}{c}A \\
(P)\end{array}$ & $\begin{array}{c}B \\
(G, P)\end{array}$ & $\begin{array}{c}C \\
(P)\end{array}$ & $\begin{array}{c}D \\
(G r)\end{array}$ & $\begin{array}{c}E \\
(G, P)\end{array}$ & $\underset{(G r)}{F}$ & $\underset{(G r)}{G}$ & $\begin{array}{c}H \\
(G r)\end{array}$ \\
\hline $\begin{array}{l}\eta_{1300^{\circ} \mathrm{C}} \\
(\text { poise })\end{array}$ & 17.0 & 12.8 & 12.7 & 9.7 & 5.9 & 3.8 & 2.5 & 1.6 \\
\hline$\left.\theta_{\text {mp }}{ }^{\circ} \mathrm{C}\right)$ & 1150 & 1120 & 1160 & 1120 & 1100 & 1170 & 1080 & 1070 \\
\hline
\end{tabular}

3. 結果と考察：メニスカス部でのスラクフィルムの流入厚さ を余、密度を $\rho$ 、重力加速度を $\mathrm{g}$ とすれば、 $\overline{d_{\mathrm{f}}}=\left(\rho \mathrm{g} \hat{\mathrm{d}}^{3} / 12 \eta_{\mathrm{u}}\right)+\left(\hat{\mathrm{d}_{\mathrm{f}}} / 2\right) \cdots \cdots$ (1) が $^{3}$ 成り立つ。 一方、ハウダー消費量の時間変化から求めた䤼片表面に付着する 平均スラクフイルム厚 $\overline{\mathrm{d}}_{\mathrm{f}}$ は 50 ～ $200 \mu$ であり、引抜速度 uに 関係なく、1300ㄷでのバゥダー溶掘時の絬度クの低下につれて 厚くなる。本実験では、(1) 式第 1 項の寄与は小さく、 $\hat{\mathrm{d}}_{\mathrm{f}} \approx 2 \overline{\mathrm{d}_{\mathrm{f}}}$ と なる。これは、 $\widehat{\mathrm{d}}_{\mathrm{f}}$ がバゥダーの絬度で異なるこを示す。低蛅度パ ウダーを遅い引抜速度で用いる場合は第 1 項が奇与する。

䤡片と鋏型壁間の接触形態を、1) 直接接触、们)スラクフイルムを介しての接触、汭) スラクフ イルムと空潪を介しての接触、に分け、定常伝熱として計算

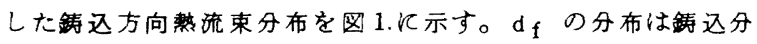
向に一定として报ったが、メニスカス付近でのスラクフィル

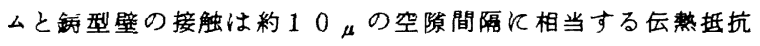
を考えない限り熱流束を説明できない。強泠された䤡型とス ラクフィルムの接触は一様でなく、凹凸を有しているものと 推察される。長辺平均熱流束とバゥダ一溶蛬時クとの関保を 図2.儿示す。 $\mathrm{U}=0.8 、 1.2 \mathrm{~m} / \mathrm{mi} \mathrm{n}$ の場合とも長辺熱流束 を極小とする枮度があり、これより高粘度、低粘度いずれの パダーを用いても長辺慗流束が增加する。增加の程度は、 高呫度㑡より低粘度㑡で顕著である。低粘度㑡での熱流束增 加は、スラクフィルムが厚くなって空隙が城少する結果であ り、高粘度㑡でのそれはスラクフイルムが薄くなることによ って、部分的に、牌と型壁が直接接触することす考えら れる。湯面変動はスラクフィルムの不均一流入をるたらす。
1) 江見ら：鉄と鍋 $\underline{60}$ (1974)、7、P981
2) 中戸ら: " $\underline{61}(1975) 12 \mathrm{~S} 481$
3) 中戸ら : " $\underline{62}(1976), 12$

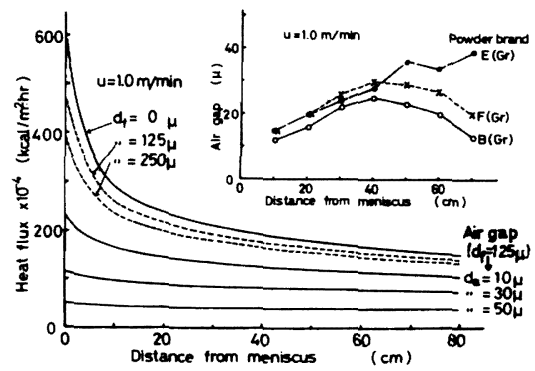

図 1. 鏻込方向熱流束分布

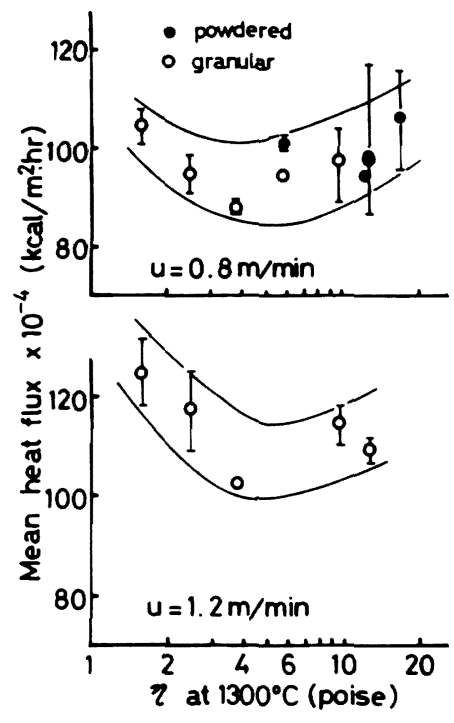

図 2. 䤶型内熱流束とパウダー 枮度 
川崎製鉄技術研究所中户突○垣生泰弘

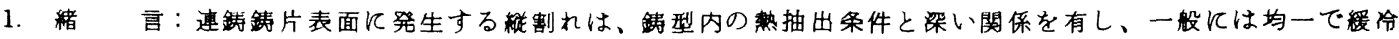
却の場合に少ないことが知られている。本報では綎割れの発生と錆 型銅板温度分布、熱抽出量との関連について述へる。

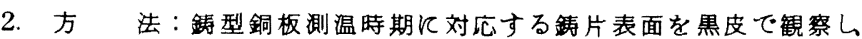
繸割れの発生位置、長さなどを記録した。耕割れは生成状況から図 1.に示す 4 つの形態飞分類し、解析した。（観察鍽：171 片）

3. 結果と考察 :

\section{1 形態別縦割れ 発生頻度}

表1. 亿示すよ 5 K、S 型が王倒的に多く、次いで $\mathrm{T}$ 型で、C 拀 よび $\mathrm{P}$ 型の発生頻度は少ない。 $\mathrm{T}$ 型は平均熱流束が低值を与える 低正灌度の場合飞生成している。

\section{2. 銅板内温度の時間変動と䊓割れ}

耧割れは銅板内の温度变動が大きい場合に発生し易い傾 向がみられ、銅板内各測定点での温度の時間変動 $(\Delta \theta / \Delta t)^{わ}$ の大きい位圈（幅方向）が契割れ発生位㯰と良く対応する。 図 2.に示すよ5に、 $\Delta \theta / \Delta t$ が大きいはど、平均綖割れ長 さも長くなる。

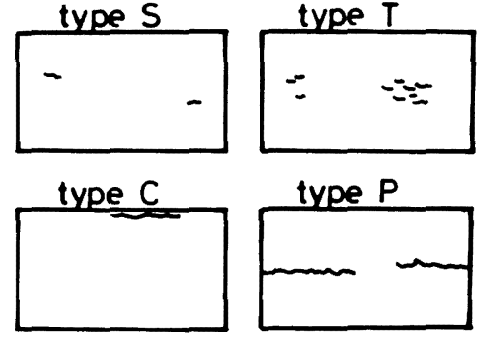

図 1. 綎割れの形態別分類 表 $1 . \underline{\mathrm{C}}$ 漂度と雓割れ状況

3.3 銅板内温度分布と穟割れ

$\mathrm{S}$ 型割九は幅方向の温度分布に偏りができ、ある程度の時間にわたり、周团より温度の低い領域が形成さ れるとそこに発生することが多い。典型的な例を図 3.に示す。T型割れは幅方向分布が $\mathrm{S}$ 型はど偏りがなく て、 $\Delta \theta / \Delta \mathrm{t}$ が大きい場合に発生している。錆込方向の温度分布と榳割れの関連は、温度が湯面下のビーク から鋏型下端にかけて順次低下寸る場合に割れは少なく、下端近くで復熱する場合に割れが多い傾向がみられた。

以上述べた銅板温度の不均一や変動は、前報りで示したよ（亿湯面変動、スラタフィルムの不均一流入、 流入,流下速度と引抜速度との不均衡などに起因している。踀割れ発生を少なくするには、操業条件を適 切に管理して、鍀型阾却を極力㚬一にすることが䏦要である。

1) 中戸ら：鉄と鍈、 $\underline{62}(1976), 12$

* 1:) 観察対象銓片に相当する時期の温度変動量をその変動時間で除した絶対値。

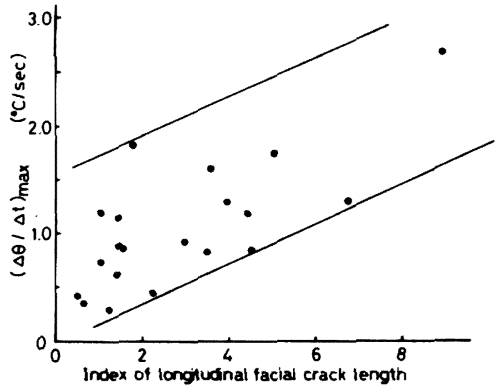

図 2. $(\Delta \theta / \Delta t)_{\max }$ と緥割九長さ

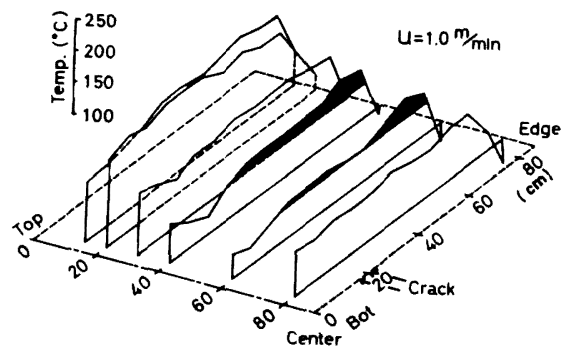

図 3. 綎割れ 発生位㯰の銅板内温度分布 
621.746.047: 669.14-412: 536.421: 539.37: 536.5

'76-S 509

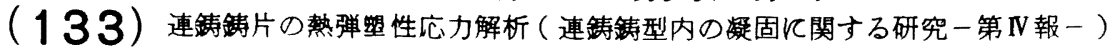

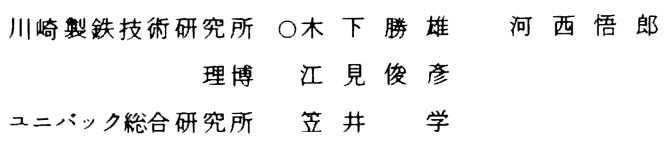

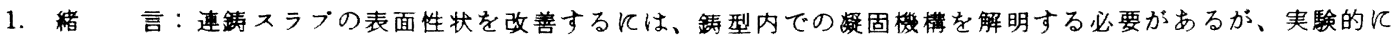
把暒するのが難しいため、理論解析により補なわねばならない。鈝型内での凝固殸の構造解析は、高 温物性値が乏しいことと同時に、確立した解析手法も無いため、はとんど行なわれていない。従来、

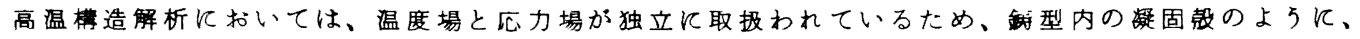
温度場と他力場が互に独立に、取扱えない場合に対しては、これまでの解析手法は、まったく役に立 たない。本報では、温度場と応力場の相関を取り入れたモテルにより、操業要因が十分に反映される よらな解析を行なった。

2. 方法：需造中の鋏片は、伝熱拈よび物質移動に関して定常状態にあるが、 本法では、温度場と応力場の相関を取り入れるため、解析面を鋂の横断面内 に固定し、2 次元非定常問題として取报った。計算のフローチャートを図1. 亿 示す。時刻 $\mathrm{t}_{\mathrm{i}}$ ておいて、 $\mathrm{t}_{\mathrm{i}-1}$ までに蓄栍された片の変位を考磨して、型 /制襇の伝熱境界条件を決め、差分法により温度分布を求める。次いで、得 られた温度分布と溶銅静王を考思し、鈵型壁を外方儿向 5 変位の拘束境界とし て、垔增分理論を用いた有限要素法により熱弹塑性解析を行なら。しかる後、 時刻を $\mathrm{t}_{\mathrm{i}+1}$ 亿す寸女て解析する。この解析は、メニスカスから始め、順次く り返して、㲏が型下端に達するまで続行した。

計算に際しては、既存の文献から多くの物性值を引用したが、塑性域での応 力ー歪関係は、別途行なった高温引張試験)から得た単軸応力一望性歪曲線

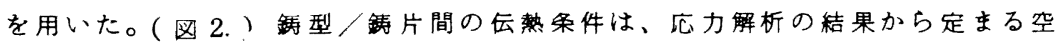
䣜と所定厚のフラックス膜を考届した。フラックス/鋏型壁間の実奻熱伝達係 数を鏳型湘温結果から定めた。

3. 結 果： $1700 \times 200 \mathrm{~m}$ 断面の、 50 キロ $\mathrm{Al} \neq$ キド鋼を $1 \mathrm{~m} / \mathrm{min}$ の引抜

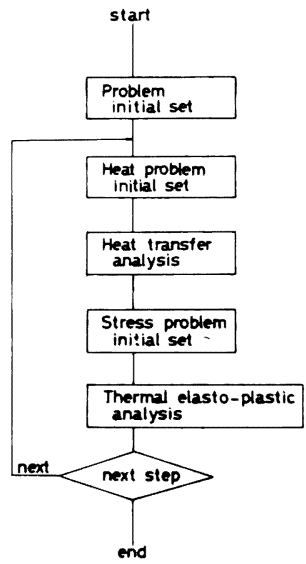
速度で込んた場合の計算結果を図3、亿示した。鈵片の幅方向

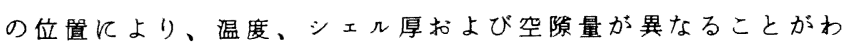
かる。さらに、鋏片表面温度、鍀型内面温度、シェ几厚および

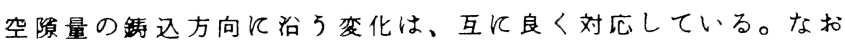
シェ几厚の成長が 2 のピッチで変化するのは要素分割のメッ シュ寸法のためである。

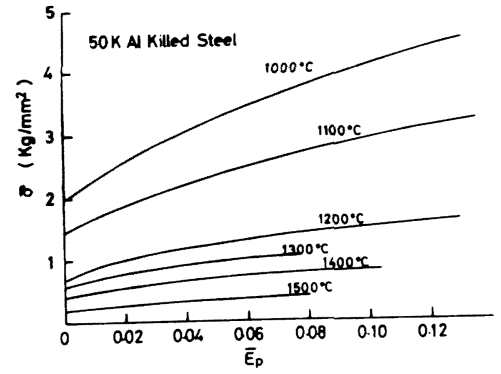

因2，高温に打ける単軸応力一塑 性歪曲線
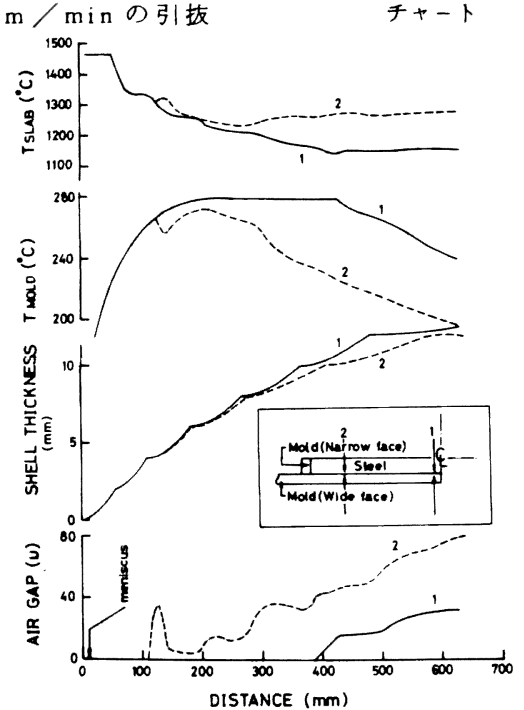

図3.銓片表面温度、鈵型内面温度 シェル厚および空陌量の変化 